\title{
The Role of High-Calcium Alkaline Sulfate-Carbonate Melts in Formation of Melilite-Monticellite Rocks and Carbonatites of the Malyi Murun Massif (Aldan, Russia)
}

Panina, L.I. and Usoltseva, L.M.

Institute of Mineralogy and Petrography. 630090 Novosibirsk, Russia.

\section{Introduction}

The Malyi Murun alkaline massif is composed of the following rocks: pyroxenite, shonkinite, fergusite, yakutite, nepheline syenite, and synnyrite (Orlova, 1987). The majority of researchers consider that this rock varieties relate to crystallization and transformation of a primordial K-basaltoid magma. Within the Malyi Murun massif there also occur peculiar lamproitic rocks (Vladykin, 1985; Panina, 1995), and in its endo- and exocontact parts -- melilite-monticellite-olivine rocks and carbonatites.

Melilite-monticellite-olivine (Me-Mont-Ol) rocks have been found at a depth of 207-260 m as thin (10-15 $\mathrm{cm}$ ) layers alternating with pyroxenites, shonkinites, and augite syenites. The rocks have a varying composition and are irregularly enriched in clinopyroxene, Al-spinel, phlogopite, and apatite. They have a maculose-banded texture governed by irregular alternation of sites enriched in olivine, clinopyroxene, melilite, and monticellite. Tiny calcite schlieren are found in melilite- and monticellite-rich zones.

Carbonatites represent calcite and benstonite varieties and are wide spread mainly in the exocontact field of fenites. Calcite carbonatites are developed as thin $(0.3-0.5 \mathrm{~m})$ vein bodies which often spatially coincide with torgolites (symplectitic quartz-calcite rocks). Benstonite carbonatites are composed of tabular and lenticular bodies.

The opinions about the genesis of Me-Mont-Ol rocks and carbonatites are contradictory. N. Vladykin (1985) considers them magmatic formations, relating the Me-Mont-Ol rocks to the earliest products, and carbonatites - to late crystallization products of alkaline-basaltoid magma. In M.Orlova's (1987) opinion the Me-Mont-Ol rocks are exocontact reactionary formations, whereas A.Konev, E.Vorob'ev, and K.Lazebnik (1966) relate their origin to a long-term effect of alkaline melts and deep-seated fluids on the country carbonate rocks. The majority of authors consider that calcite carbonatites are magmatic in origin.

Object, aim, and procedures of investigation.

The aim of our study is to elucidate the genesis and physicochemical features of formation of Me-Mont-Ol rocks. The main methods are those used for studies of inclusions of mineral-forming media, conserved in minerals. The inclusions were heated using a high-temperature heating stage combined with a microscope. The chemical composition of inclusions was determined on the electron microprobe. Salt inclusions were analyzed by scanning.

\section{Results of studies.}

In the Me-Mont-Ol rock minerals primary silicate, silicate-salt, and salt inclusions were found. The silicate inclusions occur mainly in forsterite and clinopyroxene, have a miaskitic alkaline-basaltoid composition, contain 13-14 wt.\% $\mathrm{Al}_{2} \mathrm{O}_{3}$, and are characterized by the predominance of $\mathrm{K}$ over $\mathrm{Na}$ and noticeable enrichment in $\mathrm{BaO}$ (up to $0.5 \mathrm{wt} \%$ ). They homogenize at $1300-1270^{\circ} \mathrm{C}$. The silicate-salt inclusions are observed in monticellite, less often in melilite. They have (Table) high contents of $\mathrm{MgO}$ and $\mathrm{CaO}$ (11-24 and 23-35 wt.\%, respectively), low content $\mathrm{Al}_{2} \mathrm{O}_{3}$ (1-5 wt.\%), predominance of alkalis over alumina (agpaitic type), and considerable enrichment in $\mathrm{SO}_{3}$ (up to 3-7 wt.\%). At high temperatures most of the inclusions were decrepitated, but sometimes at $1280-1260^{\circ} \mathrm{C}$ their immiscibility into silicate and salt 
components is observed. The silicate liquid is compositionally similar to lamproitic melts, whereas the salt component has a high-calcium alkaline sulfate-carbonate composition and in chemistry corresponds to salt inclusions. The latter are widespread in melilite, apatite, and spinel. Their composition (Table) is characterized by essential variations in the major elements. In general with increasing contents of $\mathrm{SO}_{3}$ in it, the contents of $\mathrm{SiO}_{2}$ decrease and amounts of $\mathrm{CaO}$ appreciably increase, and among alkalis $\mathrm{Na}$ typically prevails. On heating, part of inclusions homogenize at $1180-1060^{\circ} \mathrm{C}$, whereas the other at close temperatures $\left(1200-1190^{\circ} \mathrm{C}\right)$ separates into alkaline-sulfate and carbonate liquids. The alkaline-sulfate inclusions are the most abundant in apatite. In their composition (Table) alkalis make up 50 and even more wt.\%, potassium significantly prevails over sodium, the contents of $\mathrm{SO}_{3}$ reach $43 \mathrm{wt} . \%$, and the quantity of other components does not exceed 0.0n-0.n wt.\%. Carbonatitic melt inclusions are present in spinel, apatite, and monticellite. They homogenize at $920-930^{\circ} \mathrm{C}$. In addition to high contents of $\mathrm{CaO}$, they contain (Table) elevated amounts of $\mathrm{Na}_{2} \mathrm{O}, \mathrm{K}_{2} \mathrm{O}, \mathrm{F}$, and $\mathrm{SO}_{3}$.

\section{Discussion and conclusions.}

1. The presence of silicate inclusions of alkaline-basaltoid composition in olivine and clinopyroxene of MeMont-Ol rocks suggests that these minerals were formed from miaskitic K-alkaline-basaltoid magma at the early stage of formations of the Malyi Murun massif rocks.

2. The appearance of agpaitic high-magnesian low-alumina silicate-salt inclusions in monticellite and melilite indicates that the formation of Me-Mont-Ol rocks was influenced by one more magma which seems to ascend by the same, as K-basaltoid magma, magmatic channels. This magma is compositionally similar to lamproitic melt, is salt-enriched, had a high fluidity and through a system of cracks penetrated into zones of low pressures -- into endo- and exocontact parts of the massif. At $1280-1260^{\circ} \mathrm{C} \mathrm{high-}$ calcium alkaline sulfate-carbonate melts separated from it.

3. Salt melts contained (wt.\%) 30-40 Ca0, 5-29 $\mathrm{SO}_{3}, 1.5-11 \mathrm{Na}_{2} \mathrm{O}, 1-5 \mathrm{~K}_{2} \mathrm{O}, 1-6 \mathrm{SiO}_{2}$, up to $1 \mathrm{Al}_{2} \mathrm{O}_{3}$, $0.08 \mathrm{FeO}, 1-1.5 \mathrm{MgO}, 0.1-0.4 \mathrm{BaO}, 0.2-0.5 \mathrm{SrO}, 0.2-2.7 \mathrm{~F}$, and $0.1-0.8 \mathrm{Cl}$. When they affected early cumulates of miaskitic basaltoid magma, olivine and clinopyroxene were replaced by melilite-monticellite paragenesis.

4. When the temperature decreased, salt melt being in equilibrium with agpaitic alkaline (lamproitic) magma separated at $1190-1180^{\circ} \mathrm{C}$ into alkaline-enriched $\mathrm{Sr}$ and Ba carbonatitic melt $\left(0.3-6.6 \mathrm{SiO}_{2}\right.$, to 0.6 FeO, to $0.25 \mathrm{MgO}, 49-54 \mathrm{CaO}, 0.2-2.7 \mathrm{Na}_{2} \mathrm{O}, 0.1-1.1 \mathrm{~K}_{2} \mathrm{O}, 0.1-0.95 \mathrm{BaO}$, uo to $0.3 \mathrm{SrO}$, up to $1.1 \mathrm{~F}$, 0.02-3.6 wt. \% $\left.\mathrm{SO}_{3}\right)$ and alkaline sulfate melt (7-10 $\mathrm{Na}_{2} \mathrm{O}, 37-42 \mathrm{~K}_{2} \mathrm{O}, 37-42 \mathrm{SO}_{3}, 0.4-3$ wt.\% $\mathrm{CaO}$ ).

5. Spatial separation of these salt liquids at the macrolevel occurred as formation of calcite carbonatites and formation of different alkaline-sulfide (jerfishirite, murunskite, etc.), sulfide and sulfate (barite, celestite, barytocelestite, etc.) mineralization, which extremely typical of the Murun massif.

\section{References}

Orlova, M.P., 1987, New data on geology of the Malyi Murun massif (southwestern Aldan): Soviet Geologiy, 9, p. 83-92.

Konev, A.A., Vorob'ev, E.I., and Lazebnik. K.A., 1996, Mineralogy of the Murun alkaline massif [in Russian]: Novosibirsk, Nauka, $221 \mathrm{pp}$.

Panina, L.I., 1985. Physico-chemical conditions of crystallization of low-titanium lamproites Aldan (Siberia): Extended Abstracts of the Sixth Kimberlite Conference. Novosibirsk, p. 421-423.

Vladykin, N.V., 1985, First find of lamproites in USSR: Dokl. AN USSR, 280, p. 718-722. 
Table. Chemical composition (wt.\%) of silicate-salt (SiSa) and Salt (Sa) inclusions in minerals of Me-Mont-Ol rocks.

\begin{tabular}{|c|c|c|c|c|c|c|c|c|c|c|c|c|c|c|}
\hline Object & $\mathrm{SiO}_{2}$ & $\mathrm{Al}_{2} \mathrm{O}_{3}$ & $\mathrm{FeO}$ & $\mathrm{MgO}$ & $\mathrm{CaO}$ & $\mathrm{Na}_{2} \mathrm{O}$ & $\mathrm{K}_{2} \mathrm{O}$ & $\mathrm{P}_{2} \mathrm{O}_{5}$ & $\mathrm{BaO}$ & $\mathrm{SrO}$ & $\mathrm{F}$ & $\mathrm{Cl}$ & $\mathrm{SO}_{3}$ & Total \\
\hline \multicolumn{15}{|c|}{ Silicate-salt inclusions } \\
\hline $\mathrm{SiSa}_{h}$ in Mont & 33,4 & 1,67 & 1,8 & 21,6 & 28,3 & 0,00 & 0,9 & - & 0,1 & 0,0 & 0,0 & 0,03 & 0,14 & 87,94 \\
\hline SiSa in Mont & 38,1 & 4,26 & 0,7 & 18,1 & 28,5 & 1,08 & 0,1 & 0,02 & 0,0 & 0,1 & - & - & 3,06 & 94.02 \\
\hline \multicolumn{15}{|c|}{ Ca-rich alkaline sulfate-carbonate salt inclusions } \\
\hline $\mathrm{Sa}_{\mathrm{h}}$ in $\mathrm{Me}$ & 5,8 & 0,65 & 0,2 & 1,5 & 32,4 & 5,12 & 2,8 & 0,21 & 0,1 & - & 0,9 & 0,21 & 12,70 & 62,59 \\
\hline$S a_{h}$ in $S p$ & 1,2 & 0,95 & 0,8 & 0,5 & 31,7 & 1,32 & 2,8 & - & 0,5 & - & 2,7 & 0,63 & 13,40 & 56,50 \\
\hline $\mathrm{Sa}_{\mathrm{h}}$ in $\mathrm{Me}$ & 0,8 & 0,00 & 0,1 & 0,3 & 36,6 & 10,8 & 4,3 & 1,26 & 0,2 & 0,3 & - & - & 15,60 & 70,26 \\
\hline $\mathrm{Sa}_{\mathrm{h}}$ in $\mathrm{Me}$ & 1,8 & 0,07 & 0,0 & 0,4 & 40,3 & 4,46 & 2,7 & 1,03 & 0,2 & 0,3 & - & - & 19,80 & 71,06 \\
\hline $\mathrm{Sa}_{\mathrm{h}}$ in $\mathrm{Me}$ & 1,2 & 0,04 & 0,2 & 0,3 & 41,9 & 3,24 & 2,3 & 1,03 & 0,0 & 0,3 & - & - & 19,90 & 70,41 \\
\hline $\mathrm{Sa}_{\mathrm{h}}$ in $\mathrm{Me}$ & 0,9 & 0,00 & 0,0 & 0,3 & 41,2 & 6,07 & 3,7 & 1,52 & 0,3 & 0,4 & - & - & 20,70 & 75,09 \\
\hline $\mathrm{Sa}$ in & 2,3 & 1,00 & 0,4 & 0,5 & 39,7 & 2,02 & 8,4 & 0,00 & 0,4 & 0,5 & 1,8 & 0,19 & 29.60 & 86,81 \\
\hline \multicolumn{15}{|c|}{ Carbonatite melt inclusions } \\
\hline$S a_{h}$ in $S p$ & 1,9 & 0,08 & 0,3 & 0,0 & 53,1 & 0,52 & 0,9 & - & 0,1 & - & 1,1 & 0,00 & 8,86 & 66,96 \\
\hline $\mathrm{Sa}$ in & 0,3 & 0,00 & 0,3 & 0,1 & 56,5 & 0,09 & 1,5 & 0,01 & 0,4 & 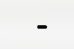 & 0,6 & 0,00 & 1,07 & 60,97 \\
\hline Sa in Mont & 0,4 & 0,00 & 0,2 & 0,3 & 57,2 & 0,14 & 0,2 & 0,01 & - & - & 0,6 & - & - & 59,05 \\
\hline $\mathrm{Sa}$ in $\mathrm{Ap}$ & 0,1 & 0,00 & 0,1 & 0,1 & 49,2 & 2,70 & 0,2 & 0,22 & 4,3 & - & 0,5 & 0,01 & 0,02 & 57,45 \\
\hline $\mathrm{Sa}$ in $\mathrm{Ca}$ & 6,6 & 0,04 & 0,1 & 0,2 & 49,8 & 1,89 & 0,0 & 0,14 & 0,0 & 0,2 & - & - & 0,03 & 59,00 \\
\hline \multicolumn{15}{|c|}{ Alkaline-sulfate melt inclusions } \\
\hline Sa in & 0,1 & 0,00 & 0,0 & 0,0 & 5,6 & 9,16 & 29,4 & - & 0,2 & - & 0,3 & 0,47 & 40,49 & 85,72 \\
\hline $\mathrm{Sa}$ in $\mathrm{Ap}$ & 0,0 & 0,00 & 0,0 & 0,0 & 0,5 & 9,27 & 42,2 & 0,00 & - & - & 0,0 & 0,00 & 42,89 & 94,86 \\
\hline
\end{tabular}

Inclusions: SiSa, Sa - unheated; $\mathrm{SiSa}_{h}, \mathrm{Sa}_{h}$ - heated up to homogenization and quenched. Minerals: Mont - monticellite, Me - melilite, Sp-Al-spinel, Ap - apatite, Ca-calcite.

Scheme of separation of salt melts from Mg-rich low-alumina agpaitic magma and evolution of salt melts

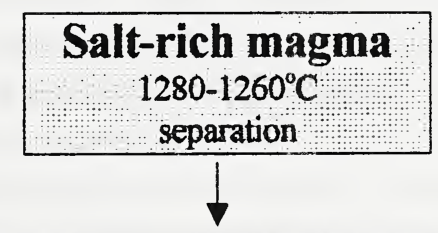

\section{Ca-rich alkaline sulfate-carbonate salt melts $1190-1180^{\circ} \mathrm{C}$ liquation}

